\title{
Biological Activity and Chemical Characteristics of Fermented Acanthopanax senticosus by Mold
}

\author{
Hee-Young Ahn', Jae-Young $\mathrm{Cha}^{2}$ and Young-Su Cho ${ }^{3}$ \\ ${ }^{1}$ Department of Medical Biosciences, Graduate School, Dong-A University, Busan 604-714, Korea \\ ${ }^{2}$ Technical Research Institute, Daesun Distilling Co, Ltd, Busan 619-951, Korea \\ ${ }^{3}$ Department of Biotechnology, Dong-A University, Busan 604-714, Korea
}

Received November 22, 2012 / Revised December 4, 2012 /Accepted December 4, 2012

\begin{abstract}
Three mold strains, Aspergillus oryzae (A. oryzae), Aspergillus kawachii (A. kawachii), and Monascus purpureus (M. purpureus), were tested for fermentation of Acanthopanax senticosus (A. senticosus) leaf, root, stem, and fruit powders. The fermented $A$. senticosus materials were then tested for bioactive materials (phenolic compounds, flavonoids, mineral and fatty acid) and biological activities (DPPH free radical scavenging activity, reducing power, and tyrosinase inhibition activity). The highest concentrations of phenolic compounds and flavonoids were NFASL at $4.11 \%$ and MPASL at $2.30 \%$, respectively. Major minerals were $\mathrm{Ca}, \mathrm{K}, \mathrm{Mg}$ and $\mathrm{Mn}$. Major fatty acids in fermented $A$. senticosus powders were palmitic, linolenic, and stearic acids. DPPH radical scavenging activity was slightly stronger in non-fermented than in fermented $A$. senticosus. Tyrosinase inhibition activity was stronger in fermented $A$. senticosus than in NFAG. The Fe/Cu reducing powers were stronger in non-fermented $A$. senticosus than in any of the fermented $A$. senticosus materials. Overall, the study provides basic data for understanding the biological activities and chemical characteristics of $A$. senticosus fermented by molds for the development of functional foods.
\end{abstract}

Key words : Acanthopanax senticosus, biological activities, tyrosinase inhibition activity

\section{서 론}

최근 들어 유산균, 효모, 바실러스, 곰팡이 등의 유익한 미생 물을 이용한 발효기술 진보로 다당체, 올리고당, 사포닌, 아미 노산, 펩타이드, 피틴산 등의 발효산물을 얻거나 또는 상호간 의 시너지 작용에 의해 생리활성효능이 상승되는 것으로 알려 져 왔다[31]. 탄수화물과 단백질을 주로 분해하는 미생물 중의 하나로 곰팡이 균주가 분비하는 효소에 의하여 생성되는 당 류, 아미노산류, 유기산류 등의 맛 성분은 제품의 품질에 결정 적인 영향을 줄 뿐만 아니라 bioconversion에 의하여 다당체, 올리고당, 아미노산류, 펩타이드류, 유기산류, 폴리페놀류 등 의 유효 성분의 생성 및 증가에 의해서 다양한 생리활성작용 을 나타내는 것으로 잘 알려져 있다[20]. 이들 곰팡이류에는 Aspergillus oryzae (A. oryzad), Aspergillus kawachii (A. kawachil), Monascus purpureus (M. purpureus) 등이 있다. A. kawachii 는 구연산과 내산성 당화효소를 생산하는 균주로 알려

\footnotetext{
*Corresponding author

Tel : +82-51-200-7586, Fax : +82-51-200-7505

E-mail : choys@dau.ac.kr

This is an Open-Access article distributed under the terms of the Creative Commons Attribution Non-Commercial License (http://creativecommons.org/licenses/by-nc/3.0) which permits unrestricted non-commercial use, distribution, and reproduction in any medium, provided the original work is properly cited.
}

져 있어 주류제조에 많이 이용되고 있으며[20], M. purpureus 균주는 홍국색소를 생산하므로 식품첨가물로 이용되기도 하 고, monacolin $\mathrm{K}$, mevinolin, lovastatin, $\gamma$-aminobutyric acid (GABA), acethylcholine과 같은 생리활성작용, 혈전 용해능 및 항산화 활성과 같은 유효성 검증에 관한 많은 연구결과가 보 고되고 있다[8]. 또한 $A$ aryzae는 오래 동안 산업용 효소생산에 이용되어 왔으며, amylase, protease 그리고 cellulase등과 같 은 다양한 효소를 분비해 전분당화력이나 단백질 분해력이 강해 우리나라 전통식품인 된장, 간장, 고추장 코오지 및 탁주 용 누룩 제조에 광범위하게 사용되고 있다 $[15,23]$.

유용 식물자원으로 두릅나무과에 속하는 가시오가피( $A$. senticosus)는 낙엽성 활엽관목으로 그 생김새는 산삼을 닮았으 며 한국의 지리산, 일본, 중국 등에 분포하고 주로 깊은 산지의 계곡에서 서식한다. 가시오가피 추출물은 한방에서 오랫동안 사용되어져 왔던 약재 중의 하나로 다양한 연구가 최근까지 계속해서 수행되어 오면서 약리학적 또는 생리학적으로 의미 있는 연구 결과들이 보고되어 졌다[19]. 현재 보고된 약리 효과 는 혈당강하[19], 체내 지질대사 개선[29], 항바이러스 활성 [13], 심근경색치료 효과[2], 항산화체계 강화 기능[12] 등 가시 오가피에 대한 많은 임상적 연구가 이루어져있다.

한편, 기능성 식품 또는 기능성 화장품을 개발하는 과정에 서 사용되고 있는 식물 추출물이 그 자체가 독성 작용을 나타 내는 경우가 종종 있으며[9], 미생물 또는 버섯 균사체로 발효 
시킴으로서 독성이 경감되는 동시에 발효 산물에 의해 혈중 지질저하 작용, 항산화 작용, tyrosinase 활성 저해 및 멜라닌 생성 억제 작용, 혈전 용해 작용 등이 증가 되며, 이 때 발효에 의해 새로운 물질이 생성되거나 기존의 생리활성 물질이 다른 물질로 전환시켜 처음과는 다른 효능을 가지게 됨으로서 이러 한 기능성 향상 연구가 시도되고 있다[26].

따라서 본 연구에서 우리나라에서 재배되고 있는 가시오 가피의 이용 가치를 향상시킬 목적으로 다량의 탄수화물을 함유한 가시오가피를 부위별로 발효시키기 위하여 3종류의 곰팡이 균주 A. oryza, A. kawachii, M. purpureus 로 발효시 킨 발효 가시오가피의 생리활성 물질 및 그 활성에 대하여 검토하였다.

\section{재료 및 방법}

\section{실험재료}

본 실험에 사용한 가시오가피(Acanthopanax senticosus)는 2010년 11월에 강원도 양구군 고지대에서 재배해 잎, 뿌리, 줄기 및 열매 부분으로 나누어 건조시켜 판매하고 있는 것을 직접 구입하여 분쇄 후 시료로 사용하였다. 가시오가피 분말 시료에 3종류의 곰팡이 균주 Aspergillus oryzae KCCM 11372 (A. oryzae), Aspergillus kawachii KCCM 32819 (A. kawachil), Monascus purpureus KCCM 12002 (M. purpureus)를 한국 미생 물보존센터로부터 분양 받아 가시오가피 발효에 사용하였다. 가시오가피의 잎, 뿌리, 줄기, 열매 분말을 전 배양 한 곰팡이 균사체에 $5 \%(\mathrm{v} / \mathrm{w})$ 수준으로 섞은 다음 $37^{\circ} \mathrm{C}$ 에서 3 일간 발효 시켰다. 이때 발효과정 중에서 건조를 막기 위하여 멸균된 증 류수를 일정량 뿌려주면서 발효를 진행시켰다. 발효된 시료는 완전히 건조시킨 후 분석에 사용하였다.

\section{발효 가시오가피 분말의 $\mathrm{pH}$ 및 산도 측정}

발효된 가시오가피 분말을 증류수에 $1 \%(\mathrm{w} / \mathrm{v})$ 농도로 희석 하여 교반한 후 $\mathrm{pH}$ meter (Methrohm 691, Swiss)로 직접 $\mathrm{pH}$ 를 측정하였다. 산도 측정은 $10 \%$ 시료액 $10 \mathrm{ml}$ 을 취하고 증류 수 $50 \mathrm{ml}$ 를 가한 후 잘 흔들어 $1 \%$ phenolphthalein 용액 4 5 방울 떨어트리고 $0.1 \mathrm{~N} \mathrm{NaOH}$ 로 적정한 후 그 소모량을 측정 하여 총 산도로 환산하였다. 추출물의 총 산도는 acetic acid 값인 0.0006 을 계산식에 적용하였다.

Total acidity (acetic acid, \%, w/v)

$=[($ titrated $0.1 \mathrm{~N} \mathrm{NaOH} \mathrm{ml} \times 0.0006) /$ sample $\mathrm{ml}] \times 100$

\section{페놀성 화합물 함량 측정}

페놀성 화합물의 함량은 Folin-ciocalteu's phenol reagent 를 이용한 Folin-Denis법[28]으로 비색시켜 spectrophotometer (Hitachi U-2900, Tokyo, Japan)의 $760 \mathrm{~nm}$ 에서 흡광도를 측정
하였다. 이 때 함량은 tannic acid를 일정 농도 $(0-500 \mu \mathrm{g} / \mathrm{ml})$ 로 하여 시료와 동일한 방법으로 측정한 표준곡선으로부터 계산 하였다.

\section{Flavonoid 함량 측정}

Flavonoid 함량은 Jia 등의 방법[17]에 따라 각 발효된 분말 을 $1 \%$ 농도로 만든 시료에 정제수와 $5 \% \mathrm{NaNO}_{2}$ 용액 및 $10 \%$ $\mathrm{AlCl}_{3} \cdot 6 \mathrm{H}_{2} \mathrm{O}$ 를 잘 혼합하여 반응시킨 용액을 spectrophotometer (Hitachi U-2900)의 $510 \mathrm{~nm}$ 에서 흡광도를 측정하였 다. 이 때 함량은 표준 물질로서 (+)-catechin hydrate을 일정 농도 $(20-200 \mu \mathrm{g} / \mathrm{ml})$ 로 시료와 동일한 방법으로 측정하여 작성 한 표준곡선으로부터 계산하였다.

\section{미네랄 함량 측정}

미네랄 함량은 $\mathrm{AOAC}$ 분석 방법[1]에 준하여 측정하였다. 즉, 각 발효 분말 $1 \mathrm{~g}$ 을 정확히 취해 $550^{\circ} \mathrm{C}$ 에서 3 시간 회화 시킨 후 $6 \mathrm{~N} \mathrm{HCl}$ 에 용해시켜 완전히 산분해시켜 수욕상에서 산을 완전히 제거하고, 이 건고물에 $3 \mathrm{~N} \mathrm{HCl}$ 를 가하여 여과한 후 원소 종류에 따라 각각 일정비율로 희석하여 원자흡광 분 광광도계(Analyst 300, Perkin Elmer, Norwalk CT, USA)를 이용하여 측정하였다.

\section{지방산 조성 분석}

지방산 분석은 Garces 및 Mancha 방법[16]으로 각 발효 분 말의 지질을 chloroform 및 methanol 혼합액(2:1)으로 추출 하였다. 추출된 지질 용액에 methanol:HCl $(5: 1, \mathrm{v} / \mathrm{v} \%)$ 용액 으로 methylation 한 후 hexane으로 지방산 methylester를 추 출하여 Omega-Wax capillary column $(30 \mathrm{~m} \times 0.25 \mu \mathrm{m}$, Supelco, USA)을 사용하여 Gas chromatography (GC-17A, Shimazdu, Koyto, Japan)로 지방산을 분석하였다. 지방산 분 석 결과는 각 지방산 표준물질과 동일한 retention time에 검 출된 것으로 하였으며, 이때 검출된 총 지방산의 면적에 대한 각 지방산의 면적 비율(\%)로 나타내었다.

\section{$\mathrm{DPPH}$ 에 의한 항산화 활성 측정}

항산화 활성 측정은 Blois 방법[3]에 따라 각 발효된 분말을 $1 \%$ 농도로 만든 시료 용액에서 a, $a^{\prime}$-diphenyl- $\beta$-picrylhydrazyl (DPPH) free radical scavenging 활성을 spectrophotometer (Hitachi U-2900)의 $528 \mathrm{~nm}$ 에서 흡광도를 측정하여 시료 첨가 구와 무첨가구의 흡광도차를 백분율(\%)로 표시하였다. 이때 활성 비교는 합성 항산화제 butylated hydroxytoluene (BHT) 를 $0.05 \%$ 농도로 첨가하여 시료와 동일한 방법으로 흡광도를 측정하였다.

DPPH radical scavenging activity $(\%)=[1$-(sample absorbance $528 \mathrm{~nm}$ )/control absorbance $528 \mathrm{~nm}] \times 100$ 


\section{$\mathrm{Fe} / \mathrm{Cu}$ 환원력 측정}

$\mathrm{Fe}$-환원력 측정은 $\mathrm{Zhu}$ 등의 방법[32]에 각 발효된 분말 $1 \%$ 농도의 시료 용액에 $0.2 \mathrm{M}$ sodium phosphate buffer $\left(\mathrm{pH}\right.$ 6.6) 및 $1 \%(\mathrm{w} / \mathrm{v})$ potassium ferricyanide $\left[\mathrm{K}_{3} \mathrm{Fe}(\mathrm{CN})_{6}\right]$ 를 혼합하여 $50{ }^{\circ} \mathrm{C}$ 에서 반응 시키고 $10 \%$ trichloroacetic acid $(\mathrm{w} / \mathrm{v})$ 상층액에 증류수 및 $0.5 \%$ ferric chloride $\left(\mathrm{FeCl}_{3}\right)$ 를 혼 합한 후 실온에서 반응 시켜 spectrophotometer (Hitachi $\mathrm{U}-2900)$ 의 $700 \mathrm{~nm}$ 에서 흡광도를 측정하였다. 한편, $\mathrm{Cu}$-환원 력 측정도 각 발효된 분말 $1 \%$ 시료액에 $0.01 \mathrm{M} \mathrm{CuCl}_{2}, 7.5$ $\mathrm{mM}$ ethanolic neocuprorine solution, $1 \mathrm{M} \mathrm{NH}_{4} \mathrm{OAc}$ buffer 를 혼합하여 상온에서 반응시킨 후 $420 \mathrm{~nm}$ 에서 흡광도를 측정하였다. 이때 환원력 비교를 위하여 천연 항산화제 ascorbic acid와 합성 항산화제 BHT를 $0.05 \%$ 농도와 동일한 방법으로 흡광도를 측정하였다.

\section{Tyrosinase 활성 측정}

Tyrosinase 활성은 Masamoto 등의 실험 방법[22]을 약간 변형하여 측정하였다. In vitro mushroom tyrosinase 활성 저 해 능력을 측정하기 위하여 $1.5 \mathrm{ml}$ plastic cuvette에 $2.5 \mathrm{mM}$ 3,4-dihydroxyphenylalanin (L-DOPA) $0.3 \mathrm{ml}, 1 \%$ 시료0.05 $\mathrm{ml}$ 및 $0.1 \mathrm{M}$ 인산완충용액 $\left(\mathrm{pH}\right.$ 6.8)을 혼합하여 $25^{\circ} \mathrm{C}$ 에서 먼저 반응시켰다. 여기에 1,380 units/ml mushroom tyrosinase (2,500 unit, Sigma Chemical Co., St. Louis MO, USA) 0.05 $\mathrm{ml}$ 를 넣은 후 $25^{\circ} \mathrm{C}$ 에서 2 분간 반응시키면서 $475 \mathrm{~nm}$ 에서 흡광 도를 측정하여 계산하였다. 대조구는 시료가 들어있지 않는 시료 용해 용액을 사용하였고, 양성대조구는 tyrosinase 저해 제로 알려진 $0.6 \mathrm{mM}$ kojic acid를 사용하였다. 이때 tyrosinase 활성 저해율 $(\%)$ 은 다음의 공식에 의하여 산출하였다.

Tyrosinase 활성 저해율 $(\%)=100-[(\mathrm{A}-\mathrm{B}) / \mathrm{A}] \times 100$

$\mathrm{A}$ 는 시료가 들어있지 않은 반응액의 0.5-1분 사이의 흡광도 차이

$\mathrm{B}$ 는 시료가 들어있는 반응액의 0.5-1분 사이의 흡광도 차이

\section{통계처리}

실험으로부터 얻어진 결과치는 one-way ANOVA 검정에 의한 평균치와 표준오차(mean $\pm \mathrm{SD})$ 로 표시하였다[11].

\section{결과 및 고찰}

\section{발효 가시오가피 분말의 $\mathrm{pH}$ 및 산도 변화}

곰팡이 균주로 발효시킨 분말의 $\mathrm{pH}$ 범위는 3.9-6.97 였으며, 가시오가피 열매의 M. purpureus 균주발효에서 낮았고, 가시 오가피 잎의 A aryzae 균주발효에서 높았다(table 1). 가시오가 피 잎, 뿌리, 열매에서는 대부분이 $\mathrm{pH}$ 가 높아지는 경향이 있는 반면에 가시오가피 열매에서 대부분이 $\mathrm{pH}$ 가 낮아지는 경향을 보였는데 당이 함유되어있으면 $\mathrm{pH}$ 가 낮아진다는 결과[18]와
Table 1. The $\mathrm{pH}$ and total acidity in fermented Acanthopanax senticosus powder by mold

\begin{tabular}{ccc}
\hline Samples & $\mathrm{pH}$ & Total acidity $(\%)$ \\
\hline NFASL & $6.09 \pm 0.01$ & $1.50 \pm 0.11$ \\
MP+ASL & $5.16 \pm 0.02$ & $1.70 \pm 0.05$ \\
AO+ASL & $6.97 \pm 0.11$ & $0.80 \pm 0.03$ \\
AK+ASL & $6.23 \pm 0.05$ & $1.20 \pm 0.04$ \\
\hline NFASR & $5.98 \pm 0.02$ & $1.50 \pm 0.05$ \\
MP+ASR & $6.24 \pm 0.04$ & $1.40 \pm 0.06$ \\
AO+ASR & $6.36 \pm 0.03$ & $1.20 \pm 0.07$ \\
AK+ASR & $5.98 \pm 0.04$ & $1.50 \pm 0.04$ \\
\hline NFASS & $5.77 \pm 0.05$ & $0.80 \pm 0.01$ \\
MP+ASS & $6.50 \pm 0.02$ & $0.60 \pm 0.01$ \\
AO+ASS & $6.45 \pm 0.03$ & $0.90 \pm 0.01$ \\
AK+ASS & $6.43 \pm 0.01$ & $0.80 \pm 0.01$ \\
\hline NFASF & $5.40 \pm 0.01$ & $2.30 \pm 0.05$ \\
MP+ASF & $3.90 \pm 0.01$ & $4.00 \pm 0.04$ \\
AO+ASF & $4.31 \pm 0.02$ & $4.70 \pm 0.04$ \\
AK+ASF & $4.09 \pm 0.05$ & $6.20 \pm 0.03$ \\
\hline
\end{tabular}

NFASL: Non-Fermented Acanthopanax senticosus Leaf; NFASR: Non-Fermented Acanthopanax senticosus Root; NFASS: Non-Fermented Acanthopanax senticosus Stem; NFASF: Non-Fermented Acanthopanax senticosus Fruit; ASL: Acanthopanax senticosus Leaf; ASR: Acanthopanax senticosus Root; ASS: Acanthopanax senticosus Stem; ASF: Acanthopanax senticosus Fruit, MP: Monascus purpureus, AO: Aspergillus oryzae, AK: Aspergillus kawachii. Values are mean $\pm \mathrm{SE}, \mathrm{n}=3$.

비슷한 양상을 보였다. 이는 가시오가피 열매에 소량의 당이 함유되어 있어 균주들이 당을 이용하여 발효함으로서 $\mathrm{pH}$ 가 낮아졌을것으로 사료된다. 또한 산도 측정에서도 열매에서 $A$ kawachii 균주 발효에서 6.2\%로 높았는데 A kawachii 균주발효 에서는 구연산을 많이 생산할 뿐만 아니라 내산성 당화 효소 를 생산하는 것으로 알려져 발효시 $\mathrm{pH}$ 를 산성으로 유지시켜 발효를 안전하게 한다고 하여 발효가시오가피의 산도를 높이 는 이유도 이에 관련성이 있는 것으로 사료된다[21].

\section{총 페놀성 화합물 함량}

페놀성 화합물은 flavonoid, catechin, tannin 류로 크게 구 분되는 2 차 대사산물로, 이들 물질들은 항산화 작용, 간기능 보호작용, 혈중 지질 저하 작용 등이 알려져 있다[4]. 본 실험에 서 사용한 가시오가피의 페놀성 화합물의 함량은 가시오가피 잎 - 뿌리 · 줄기 · 열매 추출물의 이화학적 특성 및 항산화효 과를 서술한 전보[14]의 결과와 같이 잎에서 $4.11 \%$ 로 높았으 며 뿌리, 열매, 줄기는 $1.88 \%, 1.33 \%, 0.89 \%$ 순이 었다. 하지만 M.purpureus, A oryzae, A. kawachii 균주로 발효시킨 가시오가 피에서는 발효에 의해 약간씩 낮아진 결과를 얻었다(Table 2). 이는 Cha 등[6]의 발효 참당귀에서 발효에 의해 페놀성 화합물 의 함량이 낮아진 결과와 일치하였다. 이러한 이유는 페놀성 
Table 2. Concentrations of phenolic compounds and flavonoids in fermented Acanthopanax senticosus powder by mold

\begin{tabular}{ccc}
\hline Samples & $\begin{array}{c}\text { Polyphenolic } \\
\text { compounds (\%) }\end{array}$ & Flavonoids (\%) \\
\hline NFASL & $4.11 \pm 0.04^{\mathrm{a}}$ & $1.33 \pm 0.00^{\mathrm{a}}$ \\
MP+ASL & $2.30 \pm 0.02^{\mathrm{b}}$ & $1.06 \pm 0.01^{\mathrm{b}}$ \\
AO+ASL & $1.41 \pm 0.01^{\mathrm{c}}$ & $0.76 \pm 0.00^{\mathrm{c}}$ \\
AK+ASL & $2.14 \pm 0.02^{\mathrm{d}}$ & $0.89 \pm 0.00^{\mathrm{d}}$ \\
\hline NFASR & $1.88 \pm 0.01^{\mathrm{a}}$ & $0.53 \pm 0.01^{\mathrm{a}}$ \\
MP+ASR & $1.84 \pm 0.01^{\mathrm{b}}$ & $0.72 \pm 0.00^{\mathrm{b}}$ \\
AO+ASR & $1.21 \pm 0.01^{\mathrm{c}}$ & $0.41 \pm 0.01^{\mathrm{c}}$ \\
AK+ASR & $1.59 \pm 0.01^{\mathrm{d}}$ & $0.63 \pm 0.01^{\mathrm{d}}$ \\
\hline NFASS & $0.89 \pm 0.01^{\mathrm{a}}$ & $0.35 \pm 0.00^{\mathrm{a}}$ \\
MP+ASS & $1.05 \pm 0.01^{\mathrm{b}}$ & $0.40 \pm 0.00^{\mathrm{b}}$ \\
AO+ASS & $0.96 \pm 0.01^{\mathrm{c}}$ & $0.34 \pm 0.00^{\mathrm{c}}$ \\
AK+ASS & $0.82 \pm 0.01^{\mathrm{d}}$ & $0.27 \pm 0.00^{\mathrm{d}}$ \\
\hline NFASF & $1.33 \pm 0.00^{\mathrm{a}}$ & $0.81 \pm 0.01^{\mathrm{a}}$ \\
MP+ASF & $1.24 \pm 0.02^{\mathrm{b}}$ & $0.61 \pm 0.00^{\mathrm{b}}$ \\
AO+ASF & $1.35 \pm 0.01^{\mathrm{a}}$ & $0.62 \pm 0.00^{\mathrm{c}}$ \\
AK+ASF & $1.30 \pm 0.01^{\mathrm{a}}$ & $0.57 \pm 0.00^{\mathrm{d}}$ \\
\hline
\end{tabular}

Values are mean $\pm S E, n=3$. Abbreviations are the same as in Table 1.

화합물을 많이 함유하고 있는 식물체 추출물 사용에 의한 세 포독성 작용이 추출물의 발효에 의해 독성이 경감되는 것과 무관하지 않을 것으로 사료되어 진다[25].

\section{플라보노이드 함량}

식물체에 함유되어 있는 flavonoid는 항균 활성, 항산화 효 과, 항염증 작용, 콜레스테롤 저하작용, 지방간 억제 작용 등이 보고되어 있으며, 여러 종양 세포의 성장 및 분화를 저해시키
는 효과도 다수 보고되어 있다[10]. 대부분의 식물체에서 폴리 페놀 함량이 플라보노이드보다 많이 함유 되어 있으면서 대체 로 폴리페놀 함량이 많은 식물이 플라보노이드의 함량도 많이 함유하고 있는데[7], 가시오가피 잎의 폴리페놀 함량과 플라보 노이드 함량이 다른 뿌리, 줄기, 열매보다 많이 함유하고 있는 것도 이들 결과와 일치하였다(Table 2). 또한 플라보노이드 함 량 역시 페놀성 화합물의 결과와 마찬가지로 발효에 의해 함 량이 낮아지는 경향을 보였다.

\section{미네랄 함량}

M. purpureus, A oryzae, A. kawachii 균주로 발효시킨 가시 오가피의 미네랄 함량을 측정한 결과는 Table 3과 같다. 미네 랄 성분 조성 비율을 보면 전체적으로 $\mathrm{Ca}, \mathrm{K}, \mathrm{Mg}$ 가 많이 함유 되어 있었는데 각 곰팡이 균주 발효에 의한 발효 가시오가피 분말의 미네랄 함량은 전체적으로 발효된 분말이 발효 전 분 말보다 함량이 높아 이는 발효에 의한 bioconversion의 영향 이라 사료된다. 특히 가시오가피 열매의 칼슘 함량중 M. purpureus로 발효한 분말이 발효전보다 약 8 배 가량 높았다. 한편, $\mathrm{Ca}, \mathrm{K}, \mathrm{Mg}$ 등은 인체에 중요한 필수 미네랄 성분으로 영양적 인 측면에서도 매우 중요한 것으로 알려져 있다.

\section{지방산 조성}

곰팡이 균주에 의해 발효된 가시오가피 분말의 지방산 분석 결과 포화 지방산으로 myristic acid, palmitic acid, stearic acid, arachidic acid 일가 불포화 지방산으로 palmitoleic acid, oleic acid 다가 불포화 지방산으로 linoleic acid, linolnic acid 가 검출되었으며, 그 중 주요 지방산 성분으로 palmitic acid, stearic acid, oleic acid 가 주된 지방산으로 확인되었다(Table

Table 3. Mineral contents in fermented Acanthopanax senticosus powder by mold

\begin{tabular}{|c|c|c|c|c|c|c|c|}
\hline & \multicolumn{7}{|c|}{ Mineral concentrations (ppm) } \\
\hline & Calcium & Potassium & Magnesium & Manganese & Sodium & Iron & Zinc \\
\hline NFASL & $127.66 \pm 0.87$ & $77.20 \pm 0.87$ & $19.50 \pm 0.06$ & $5.08 \pm 0.02$ & $4.78 \pm 0.33$ & $1.48 \pm 0.02$ & $0.27 \pm 0.00$ \\
\hline $\mathrm{MP}+\mathrm{ASL}$ & $41.40 \pm 0.10$ & $171.26 \pm 0.33$ & $16.22 \pm 0.05$ & $0.00 \pm 0.00$ & $3.23 \pm 0.14$ & $0.82 \pm 0.17$ & $0.32 \pm 0.00$ \\
\hline $\mathrm{AO}+\mathrm{ASL}$ & $296.95 \pm 1.83$ & $152.53 \pm 0.35$ & $39.73 \pm 0.14$ & $12.51 \pm 0.07$ & $7.24 \pm 0.13$ & $4.41 \pm 0.21$ & $0.54 \pm 0.00$ \\
\hline $\mathrm{AK}+\mathrm{ASL}$ & $298.72 \pm 0.47$ & $158.84 \pm 0.44$ & $40.50 \pm 0.07$ & $12.39 \pm 0.02$ & $6.59 \pm 0.17$ & $4.24 \pm 0.17$ & $0.39 \pm 0.00$ \\
\hline NFASR & $33.70 \pm 0.03$ & $202.66 \pm 0.55$ & $44.85 \pm 0.03$ & $1.28 \pm 0.03$ & $2.60 \pm 0.00$ & $2.09 \pm 0.02$ & $0.08 \pm 0.00$ \\
\hline $\mathrm{MP}+\mathrm{ASR}$ & $128.81 \pm 0.37$ & $76.61 \pm 0.20$ & $17.01 \pm 0.06$ & $3.10 \pm 0.01$ & $5.33 \pm 0.16$ & $7.09 \pm 0.30$ & $0.51 \pm 0.00$ \\
\hline $\mathrm{AO}+\mathrm{ASR}$ & $81.24 \pm 0.17$ & $51.43 \pm 0.15$ & $12.96 \pm 0.04$ & $2.14 \pm 0.00$ & $4.57 \pm 0.13$ & $4.22 \pm 0.18$ & $0.22 \pm 0.00$ \\
\hline $\mathrm{AK}+\mathrm{ASR}$ & $106.12 \pm 0.54$ & $66.65 \pm 0.30$ & $15.43 \pm 0.10$ & $2.70 \pm 0.02$ & $4.78 \pm 0.16$ & $6.27 \pm 0.19$ & $0.41 \pm 0.00$ \\
\hline NFASS & $53.08 \pm 0.09$ & $18.09 \pm 0.06$ & $7.63 \pm 0.02$ & $1.85 \pm 0.01$ & $3.37 \pm 0.18$ & $1.22 \pm 0.28$ & $0.19 \pm 0.00$ \\
\hline $\mathrm{MP}+\mathrm{ASS}$ & $68.25 \pm 0.13$ & $28.96 \pm 0.05$ & $9.02 \pm 0.03$ & $2.76 \pm 0.00$ & $3.58 \pm 0.23$ & $1.05 \pm 0.22$ & $0.28 \pm 0.00$ \\
\hline $\mathrm{AO}+\mathrm{ASS}$ & $89.50 \pm 0.05$ & $33.24 \pm 0.08$ & $10.59 \pm 0.04$ & $3.32 \pm 0.01$ & $4.21 \pm 0.33$ & $1.74 \pm 0.15$ & $0.37 \pm 0.00$ \\
\hline $\mathrm{AK}+\mathrm{ASS}$ & $25.81 \pm 0.21$ & $15.93 \pm 0.16$ & $5.19 \pm 0.45$ & $0.73 \pm 0.01$ & $2.45 \pm 0.23$ & $0.56 \pm 0.11$ & $0.17 \pm 0.02$ \\
\hline NFASF & $36.50 \pm 0.04$ & $98.62 \pm 0.41$ & $71.65 \pm 0.33$ & $2.05 \pm 0.33$ & $1.20 \pm 0.00$ & $0.00 \pm 0.00$ & $0.07 \pm 0.00$ \\
\hline $\mathrm{MP}+\mathrm{ASF}$ & $291.25 \pm 0.77$ & $172.85 \pm 0.58$ & $40.16 \pm 0.19$ & $11.96 \pm 0.01$ & $6.51 \pm 0.08$ & $3.75 \pm 0.30$ & $0.54 \pm 0.00$ \\
\hline $\mathrm{AO}+\mathrm{ASF}$ & $44.77 \pm 0.18$ & $178.93 \pm 0.53$ & $17.14 \pm 0.06$ & $0.00 \pm 0.00$ & $3.60 \pm 0.08$ & $0.57 \pm 0.40$ & $0.21 \pm 0.00$ \\
\hline $\mathrm{AK}+\mathrm{ASF}$ & $49.52 \pm 0.25$ & $194.67 \pm 0.79$ & $18.38 \pm 0.02$ & $0.00 \pm 0.00$ & $3.39 \pm 0.23$ & $0.84 \pm 0.05$ & $0.17 \pm 0.00$ \\
\hline
\end{tabular}

Values are mean $\pm \mathrm{SE}, \mathrm{n}=3$. Abbreviations are the same as in Table 1 . 
Table 4. Fatty acid compositions in Fermented Acanthopanax senticosus powder by mold

(\% for area of total fatty acids)

\begin{tabular}{cccccccccccc}
\hline Fatty acid & $\begin{array}{c}\text { Myristic } \\
\text { acid } \\
(14: 0)\end{array}$ & $\begin{array}{c}\text { Palmitic } \\
\text { acid } \\
(16: 0)\end{array}$ & $\begin{array}{c}\text { Palmitoleic } \\
\text { acid } \\
(16: 1, \mathrm{n}=9)\end{array}$ & $\begin{array}{c}\text { Stearic } \\
\text { acid } \\
(18: 0)\end{array}$ & $\begin{array}{c}\text { Oleic } \\
\text { acid } \\
(18: 1, \mathrm{n}=9)\end{array}$ & $\begin{array}{c}\text { Linoleic } \\
\text { acid } \\
(18: 2, \mathrm{n}=6)\end{array}$ & $\begin{array}{c}\text { Linolenic } \\
\text { acid } \\
(18: 3, \mathrm{n}=3)\end{array}$ & $\begin{array}{c}\text { Arachidic } \\
\text { acid } \\
(20: 0)\end{array}$ & SFA & MUFA & PUFA \\
\hline NFASL & 8.13 & 67.78 & 8.50 & 6.24 & 4.26 & N.D & 5.09 & N.D & 82.15 & 12.76 & 5.09 \\
MP+ASL & 10.69 & 59.34 & 6.82 & 9.10 & 7.13 & N.D & 6.61 & N.D & 79.13 & 14.26 & 6.61 \\
AO+ASL & 12.05 & 56.72 & 5.44 & 10.85 & 7.70 & N.D & 7.25 & N.D & 79.62 & 13.13 & 7.24 \\
AK+ASL & 11.45 & 51.54 & 5.45 & 12.68 & 9.72 & N.D & 9.15 & N.D & 75.67 & 15.18 & 9.15 \\
\hline NFASR & 9.21 & 30.75 & N.D & 11.73 & 9.36 & 20.96 & 6.59 & 11.40 & 63.09 & 9.36 & 27.56 \\
MP+ASR & 14.85 & 25.49 & N.D & 13.88 & 9.71 & 11.73 & 9.07 & 15.27 & 69.49 & 9.71 & 20.80 \\
AO+ASR & 16.07 & 27.64 & N.D & 16.14 & 8.12 & 4.93 & 10.33 & 16.78 & 76.62 & 8.12 & 15.26 \\
AK+ASR & 14.24 & 24.59 & N.D & 15.30 & 9.37 & 8.24 & 11.49 & 16.77 & 70.90 & 9.37 & 19.73 \\
\hline NFASS & 10.62 & 38.51 & 4.55 & 11.84 & 8.13 & 3.16 & 11.60 & 11.60 & 72.57 & 12.67 & 14.76 \\
MP+ASS & 5.20 & 54.80 & 2.50 & 12.31 & 12.29 & 2.81 & 5.08 & 5.01 & 77.32 & 14.79 & 7.89 \\
AO+ASS & 12.21 & 28.14 & 4.11 & 11.58 & 9.43 & 12.39 & 10.09 & 12.05 & 63.99 & 13.53 & 22.48 \\
AK+ASS & 13.63 & 24.89 & 5.05 & 13.63 & 8.00 & 8.17 & 11.96 & 14.66 & 66.82 & 13.06 & 20.12 \\
\hline NFASF & 10.90 & 59.14 & 4.57 & 3.66 & 16.74 & N.D & 5.00 & N.D & 73.70 & 21.30 & 5.00 \\
MP+ASF & 10.51 & 55.44 & 3.91 & 4.97 & 20.26 & N.D & 4.91 & N.D & 70.91 & 24.14 & 4.91 \\
AO+ASF & 6.26 & 37.16 & 2.54 & 5.05 & 46.22 & N.D & 2.76 & N.D & 48.47 & 48.77 & 2.76 \\
AK+ASF & 12.21 & 59.43 & 3.98 & 4.64 & 16.01 & N.D & 3.74 & N.D & 76.28 & 19.98 & 3.74 \\
\hline
\end{tabular}

Values are mean $\pm S E, n=3$. Abbreviations are the same as in Table 1.

SFA; saturated fatty acid, MUFA; monounsaturated fatty acid, PUFA; polyunsaturated fatty acid.

4). 전체적으로 포화지방산이 약 $60-80 \%$ 로 대부분을 차지하고 있었다.

\section{$\mathrm{DPPH}$ free radical에 의한 전자공여 활성}

폴리페놀 및 플라보노이드 화합물의 항산화 활성을 간단히 측정할 수 있는 동시에 실제 항산화 활성과도 매우 연관성이 높기 때문에 많이 이용되고 있다[5]. 전보[14]에 결과에 따라 뿌리에서 가장 높은 약 $80 \%$ 의 활성을 보였지만 발효에 의하여 활성이 낮아졌고 잎에서도 마찬가지로 약 $79 \%$ 의 활성이 발효 에 의해 낮아졌다(Fig. 1). 하지만 가시오가피 줄기는 발효전 분말은 약 $27 \%$ 의 활성을 나타냈지만 M. purpureus와 A. oryzae 균주로 발효시킨 분말은 약 $73 \%$ 와 $61 \%$ 로 활성이 증가했다. 또한, 가시오가피 열매도 발효전 분말은 약 $58 \%$ 의 활성을 나 타냈지만 M. purpureus와 A. oryzae 균주로 발효시킨 분말은 약 $77 \%$ 와 $69 \%$ 로 활성이 증가했다. 한편 본 실험에서 양성 대 조군으로 사용한 시판 합성 항산화제인 $\mathrm{BHT} 0.05 \%$ 처리 농도 에서는 약 $90 \%$ 로 $\mathrm{DPPH}$ 전자공여능에 의한 항산화 활성이 매우 높았다. 이상의 결과에서 발효 가시오가피 잎, 뿌리, 줄기 및 열매의 항산화 활성은 곰팡이 균주와 부위에 따라 차이가 나타났다.

\section{환원력 효과}

환원력(reducing power) 활성 정도는 수소 원자를 제공하 는 유리 라디칼의 연쇄 반응으로 금속 이온을 환원시키는 정 도를 흡광도 값으로 나타내는 것으로, 환원력의 세기가 높을 수록 항산화 활성이 높다는 것을 나타낸다. 본 연구결과에서

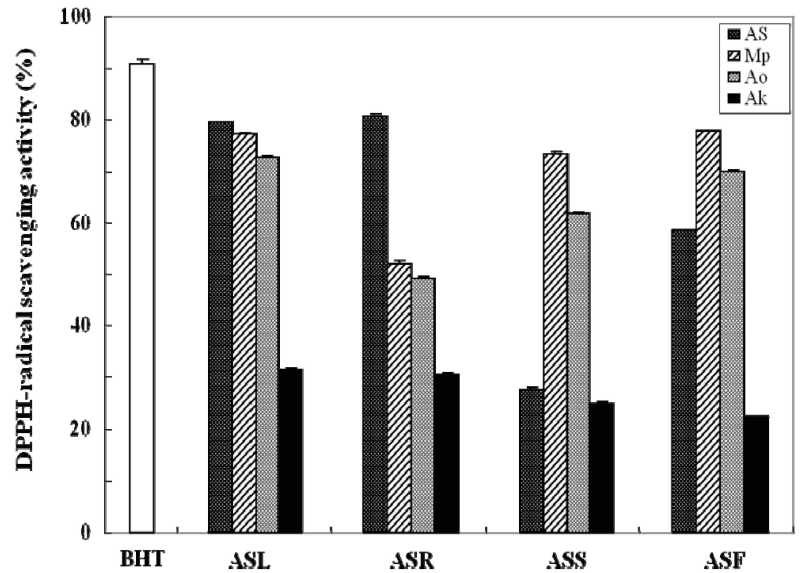

Fig. 1. DPPH radical scavenging activities in Fermented Acanthopanax senticasus powder by mold. BHT: butylated hydroxyl toluene $(0.05 \%)$; Abbreviations are the same as in Table 1 . Values are mean $\pm S E, n=3$.

$\mathrm{Fe}$-환원력은 대조구로 사용한 BHT 및 ascorbic acid $0.05 \%$ 의 농도 처리에서 1.242 및 1.118 을 나타내어 가시오가피 잎을 제외한 나머지 시료보다 월등히 높았다(Fig. 2). 줄기를 제외한 대부분의 시료에서 발효 전 시료보다 M. purpureus, A. oryzae, A. kawachii 균주로 발효시킨 가시오가피에서는 $\mathrm{Fe}$-환원력이 다소 낮아지는 경향을 보였다. 또한 $\mathrm{Cu}$-환원력도 대조구인 BHT 및 ascorbic acid $0.05 \%$ 의 농도 처리에서 2.145 및 2.032를 나타내어 환원력이 높았지만 M. purpureus, A. oryzae, A. kawachii 균주로 발효시킨 가시오가피에서는 $\mathrm{Fe}$-환원력과 마찬 가지로 환원력이 낮아지는 경향을 보였다(Fig. 3). 한방 생약 
Table 5. Inhibition activity of tyrosinase in Fermented Acanthopanax senticosus powder by mold

\begin{tabular}{cccccc}
\hline \multirow{2}{*}{ Composition } & \multirow{2}{*}{ Conc. $(\%)$} & Leaf & Root & Syrosinase inhibition activity (\%) & Fruit \\
\cline { 3 - 6 } & 1 & \multicolumn{3}{c}{$90.16 \pm 0.89^{\mathrm{a}}$} \\
Ascorbic acid & 1 & $90.72 \pm 1.39^{\mathrm{a}}$ \\
Kojic acid & 1 & $20.62 \pm 0.68^{\mathrm{b}}$ & $9.01 \pm 0.30^{\mathrm{ab}}$ & $5.51 \pm 1.34^{\mathrm{ac}}$ & $13.57 \pm 2.25^{\mathrm{a}}$ \\
AS & 1 & $23.21 \pm 3.27^{\mathrm{b}}$ & $4.80 \pm 1.41^{\mathrm{a}}$ & $17.04 \pm 0.83^{\mathrm{b}}$ & $26.32 \pm 0.45^{\mathrm{b}}$ \\
MP & 1 & $24.16 \pm 1.48^{\mathrm{b}}$ & $12.71 \pm 2.34^{\mathrm{b}}$ & $9.12 \pm 2.07^{\mathrm{a}}$ & $27.22 \pm 4.35^{\mathrm{b}}$ \\
AO & 1 & $19.43 \pm 1.28^{\mathrm{b}}$ & $14.08 \pm 2.86^{\mathrm{b}}$ & $7.20 \pm 1.53^{\mathrm{ac}}$ & $12.71 \pm 1.03^{\mathrm{a}}$ \\
AK & 1 & & & &
\end{tabular}

Values are mean $\pm S E, n=3$. Abbreviations are the same as in Table 1.

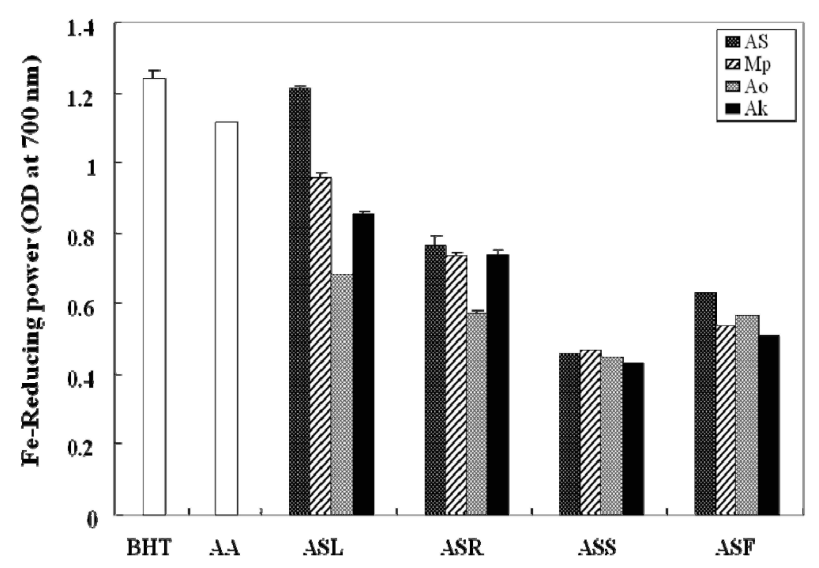

Fig. 2. Fe-Reducing power in Fermented Acanthopanax senticosus powder by mold. BHT: butylated hydroxyl toluene; AA: Ascorbic acid; Abbreviations are the same as in Table 1. Values are mean \pm SE, $n=3$.



Fig. 3. Cu-Reducing power in Fermented Acanthopanax senticosus powder by mold. BHT: butylated hydroxyl toluene; AA: Ascorbic acid; Abbreviations are the same as in Table 1. Values are mean \pm SE, $n=3$.

제인 참당귀가 0.07에서 발효 후 0.04-0.05로 다소 떨어지는 것으로 나타나[6], 본 실험 결과와도 일치하였다. 그러나 더덕 의 경우 0.34 에서 발효에 의해 0.65 로 활성이 증가된 것으로
나타나 본 실험 결과와는 다른 양상을 보였다[24]. 이러한 차이 는 발효 더덕의 경우 총 페놀 및 플라보노이드 함량이 생더덕 보다 많이 함유됨으로서 환원력 활성이 증가된 것으로 보여 지지만, 본 연구에서는 이들 두 성분이 발효에 의해 증가되지 않았기 때문인 것으로 사료 되어진다.

\section{Tyrosinase 활성}

생물체에 분포되어 있는 색소 성분인 멜라닌은 인체 내에서 표피층의 멜라노사이트라는 색소세포 내의 멜라노좀에서 합 성되는데, tyrosinase 효소에 의해 tyrosin이 DOPA (3,4dihydroxy-phenylalanine) 또는 DOPA 퀴논으로 산화 및 중 합 반응에 의해 만들어 진다[30]. 이때 생성되는 멜라닌이 피부 자극에 대해 저항력을 높여주지만, 과도한 멜라닌 생성은 색 소 침착과 피부 손상을 일으키는데, 이때 피부 미백효과를 측 정하는 하나의 지표로 tyrosinase 활성을 측정하고 이를 효과 적으로 저해하는 생리활성물질을 탐색하는 것은 향장산업에 서 매우 중요한 부분이다. 국내에 자생하고 있는 한방 생약재 중에서 수용성 추출물인 상백피 $63 \%$, 감초 $13-52 \%$, 작약 $44 \%$, 천궁 $28 \%$, 복령 $4 \%$ 의 tyrosinase 활성 저해효과가 보고되었다 [27]. 본 실험에서 양성 대조구로 사용한 ascorbic acid, kojic acid 의 $1 \%$ 처리 농도에서 tyrosinase 저해 활성이 각 각 90.16 및 90.72로 높게 나타났다(Table 5). 그러나 본 실험에서 가시 오가피 잎, 뿌리, 줄기, 열매는 약 $20 \%$ 이하로 매우 낮은 수준 이었지만 가시오가피 잎에서 M. purpureus, A. oryzae 균주로 발효 후 $20.62 \%$ 에서 $23.21 \%$ 및 $24.16 \%$ 로 활성이 약간 증가 하였다. 가시오가피 뿌리는 A oryzae, A kawachii 균주로 발효 후 $9.01 \%$ 에서 $12.71 \%$ 및 $14.08 \%$ 로 증가했고, 가시오가피 줄기 는 M. purpureus, A. oryzae, A. kawachii 균주 모두에서 발효 후 $5.51 \%$ 에서 $17.04 \%, 9.12 \%$ 및 $7.2 \%$ 로 활성이 증가했다. 또한 가시오가피 열매는 $13.57 \%$ 에서 $26.32 \%$ 및 $27.22 \%$ 로 활성이 증가했다. 따라서 한방 생약재 유래의 미백 기능성 화장품 개 발을 위해서 곰팡이 균사체로 발효시켜 사용함으로서 tyrosinase 저해 활성 효과를 기대 할 수 있을 것으로 사료 되어 진다. 


\section{References}

1. A.O.A.C. 1975. Official methods of analysis. 12th eds., Association of official analytical chemists. Washington DC, USA

2. Afanaseva, T. N. and Lebkova, N. P. 1987. Effect of Eleutherococcus on the subcelluolar structures of the heart in experimental myocardianl infarct. Biull. Eksp. Biol. Med 103, 212-215.

3. Blois, M. S. 1958. Antioxidant determination by the use of a stable free radical. Nature 26, 1199-1204.

4. Cha, J. Y., Kim, H. J., Chung, C. H. and Cho, Y. S. 1999. Antioxidative activities and contents of polyphenolic compound of Cudrania tricuspidata. J. Korean Soc. Food Sci. Nutr. 28, 1310-1315.

5. Cha, J. Y., Kim, H. J., Chung, C. H. and Cho, Y. S. 1999. Antioxidative activities and contents of polyphenolic compound of Cudrania tricuspidata. J. Korean Soc. Food Sci. Nutr. 28, 1310-1315.

6. Cha, J. Y., Kim, H. W., Heo, J. S., Ahn, H. Y., Eom, K. E., Heo, S. J. and Cho, Y. S. 2010. Ingredients Analysis and Biological Activity of Fermented Angelica gigas Nakai by Mold. J. Life Sci. 20, 1385-1393.

7. Cha, J. Y., Ahn, H. Y., Eom, K. E., Park, B. K., Jun, B. S. and Cho, Y. S. 2009. Antioxidative activity of Aralia elata shoot and leaf extracts. J. Life Sci. 19, 652-658.

8. Cha, J. Y., Park, J. C., Ahn, H. Y., Eom, K. E., Park, B. K., Jun, B. S. and Cho, Y. S. 2009. Effect of Monascus purpureus fermented Korean red ginseng powder on the serum lipid levels and antioxidative activity in rats. J. Korean Soc. Food Sci. Nutr. 38, 1153-1160.

9. Cha, J. Y., Kim, Y. S., Kang, P. D., Ahn, H. Y., Eom, K. E. and Cho, Y. S. 2010. Biological activity and chemical characteristics of fermented silkworm powder by mold. J. Life Sci. 20, 237-244.

10. Choi, Y. M., Gu, J. B., Kim, M. H. and Lee, J. S. 2008. Antioxidant and antiproliferative activities of methanolic extracts from thirty Korean medicinal plants. Food Sci. Biotechnol. 17, 1235-1239.

11. Duncan, D. B. 1959. Multiple range and multiple $F$ test. Biometrics 1, 1-42.

12. Ferrando, A., Vila, L., Voces, J. A., Cabrol, A. C., Alvarez, A. I. and Prieto, J. G. 1999. Effects of ginseng extract on various haematological parameters during aerobic exercise in the rat. Planta Med 65, 288-290.

13. Glatthaar-Saamuller B., Sacher, F. and Esperester, A. 2001. Antiviral activity of an extract derived from root Eleutherococcus senticos. Antiviral Res. 50, 223-228

14. Heo, S. J., Ahn, H. Y., Kang, M. J., Lee, J. H., Cha, J. Y. and and Cho, Y. S. 2011. Antioxidative Activity and Chemical Characteristics of Leaves, Roots, Stems and Fruits Extracts from Acanthopanax senticosus. J. Life Sci. 21, 1052-1059.

15. Hwang, J. Y., Choi, S. H. and Kim, S. K. 2009. Optimal conditions for the production of salt-tolerant protease from
Aspergillus sp. 101 and and its characteristics. J. Korean Soc. Food Sci. Nutr. 38, 1612-1617.

16. Jayaprakasha, G. K., Singh, R. P. and Sakariah, K. K. 2001. Antioxidant activity of grape seed (Vitis vinifera) extracts on peroxidation models in vitro. Food Chem 73, 285-290.

17. Jia, Z., Tang, M. and Wu, J. 1999. The determination of flavonoid contents in mulberry and thier scavenging effects on superoxide radicals. Food Chem 64, 555-559.

18. Kim, H. S., Park, I. B., Lee, Y. J., Shin, G. W., Lim, J. Y., Park, J. W. and Jo, Y. C. 2010. Characteristic of Glasswort (Salicornia Herbacea L.) Mixture Fermentation Utilizing Aspergillus oryzae. J. Korea Soc. Food Sci. Nutr. 39, 1384-1390.

19. Ko, S. K., Kim, J. S., Choi, Y. E., Lee, S. J., Park, K. S. and Chung, S. H. 2002. Anti-diabetic effects of mixed water extraction from Gingseng Radix Rubra Acanthopanacis cortex and cordyceps. Korean J. Pharmacogen. 33, 337-342

20. Lee, T. S. and Choi, J. Y. 2005. Volatile flover components in mash of Takju prepared by using Aspergillus kawachill nuruks. Korean J. Food Technol. 37, 944-950.

21. Lee, T. S. and Choi, J. Y. 2005. Volatile flovor components in mash of Takju prepared by using Aspergillus kawachii nuruks. Korean J. Food Sci. Technol. 37, 944-950.

22. Masamoto, Y., Ando, H., Murata, Y., Shimoishi, Y., Tada, M. and Takahata, K. 2003. Mushroom tyrosinase inhibitory activity of esculetin isolated from seeds of Euphorbia lathyris L. Biosci. Biotechnol. Biochem 67, 631-634.

23. Park, H. K. and Kim, J. K. 2008. Optimal manufacturing conditions for Korean soybean paste and soy sauce, using Aspergillus oryzae AJ 100 as a flavor improver. Food Sci. Biotechnol. 17, 208-211.

24. Park, S. J., Song, S. W., Seong, D. H., Park, D. S., Kim, S. S., Gou, J., Ahn, J. H., Yoon, W. B. and Lee, H. Y. 2009. Biological acivities in the extract if fermented Codonopsis lanceolata. J. Korean Soc. Food Sci. Nuti. 38, 983-988.

25. Park, S. S., Ryu, Y. B., Lee, Y. H., Cho, Y. U., Cho, S. J., Choi, Y. J., Park, K. H. and Gal, S. W. 2007. Inhibition of melanin synthesis by mycelial culture broth of Paecilomyces japonica in the mulberry leaf extract. J. Life Sci. 17, 816-821.

26. Park. S. J., Song, S. W., Seong, D. H., Park, D. S., Kim, S. S., Gou, J., Ahn, J. H., Yoon, W. B. and Lee, H. Y. 2009. Biological activities in the extract if fermented Codonopsis lanceolata. J. Korean Soc. Food Sci. Nutr. 38, 983-988.

27. Pyo, Y. H. 2007. Comparison of antioxidant potentials in methanolic extracts from soybean and rice fermented with Monascus sp. Food Sci. Biotechnol. 16, 451-456.

28. Swain, T., Hillis, W. E. and Oritega, M. 1959. Phenolic constituents of Ptunus domestica. I. Quantitative analysis of phenolic constituents. J. Sci. Food Agric. 10, 83-88.

29. Szolomicki, J., Samochowies, L. M., Drozdzik, W. J. and Szolomicki, S. 2000. The influence of active components of Eleutherococcus senticosus on cellular defense and physical fitness in man. Phytother. Res. 14, 30-35

30. Vile, G. F. and Tyrrell, R. M. 1995. UVA radiation-induced oxidative damage to lipid and protein in vitro and in human skin fibroblast is dependent on iron and singlet oxygen. Free Radical Biol. Med 18, 721-730. 
31. Yang, S. A., Im, N. K. and Lee, I. S. 2007. Effects of metanolic extract from Salvia miltiorrhiza Bunge on in vitro antithrombotic and antioxidative activities. Korean J. Food Technol. 39, 83-87.
32. Zhu, Q. V., Hackman, R. M., Jodilensunsa, X. X., Holt, R. R. and Keen, C. L. 2002. Antioxidative activities of Oolong tea. J. Agric. Food Chem 50, 6229-6234.

\section{초록 : 곰팡이 발효 가시오가피의 이화학적 특성과 생리활성}

안희영 $\cdot$ 차재영 ${ }^{2}$ 조영수 ${ }^{*}$

( ${ }^{1}$ 동아대학교 대학원 의생명과학과, ${ }^{2}$ 대선주조(주) 기술연구소, ${ }^{3}$ 동아대학교 생명공학과)

미생물 발효에 의한 부위별 가시오가피의 생리활성 작용 및 물질을 개발하기 위한 기초 자료를 얻을 목적으로 Aspergillus oryzae KCCM 11372, Aspergillus kawachii KCCM 32819, Monascus purpureus KCCM 12002 3종의 곰팡 이 균주를 본 실험에 사용하였으며, 이들에 의한 부위별 발효 가시오가피의 폴리페놀, 플라보노이드와 미네랄 함량, 지방산 조성, 항산화 활성, 미백 효능을 비교 검토하였다. 곰팡이 균주로 발효시킨 분말의 $\mathrm{pH}$ 범위는 3.9-6.97 였으며, 미네랄 성분 조성 비율은 $\mathrm{Ca}, \mathrm{K}, \mathrm{Mg}$ 순으로, 각 곰팡이 균주 발효에 의한 발효 가시오가피 분말 의 미네랄 함량은 전체적으로 발효된 분말이 발효 전 분말보다 함량이 높았다. 주요 지방산 조성은 palmitic acid, stearic acid, oleic acid 으로 전체적으로 포화지방산이 대부분을 차지하고 있었다. 항산화 활성은 가시오가피 줄 기에서 발효전 분말은 약 $27 \%$ 의 활성을 나타냈지만 M. purpureus와 A. oryzae 균주로 발효시킨 분말은 약 $73 \%$ 와 $61 \%$ 로 활성이 증가했다. 또한, 가시오가피 열매도 발효전 분말은 약 $58 \%$ 의 활성을 나타냈지만 M. purpureus와 A. oryzae 균주로 발효시킨 분말은 약 $77 \%$ 와 $69 \%$ 로 활성이 증가했다. 미백 효능은 가시오가피 잎, 뿌리, 줄기, 열매는 약 $20 \%$ 이하로 매우 낮은 수준이었지만 가시오가피 잎과 뿌리에서 발효에 의해 활성이 증가하는 경향을 보였다. 이상의 실험결과에서 곰팡이 균주에 의한 부위별 발효 가시오가피의 생리활성 효과 및 이화학적 특성이 발효 전 가시오가피 분말보다 강화됨으로써 건강기능식품이나 화장품의 천연 항산화제 소재로서의 이용 가능성 이 높다고 할 수 있다. 